\title{
A PÁLYAKEZDŐ TANÁROK \\ BEVEZETŐ TÁMOGATÁSI RENDSZERÉVEL KAPCSOLATOS UNIÓS TÖREKVÉSEKRŐL
}

\section{STÉGER CSILla}

a Nemzeti Erőforrás Minisztérium Felsőoktatási Főosztályának

képzési referense

steger.csilla@nefmi.gov.hu

\begin{abstract}
A 2009. november 26-án az Európai Unió Tanácsa (továbbiakban: Tanács), és a tagállamok kormányainak a Tanács keretében ülésezö képviselöi elfogadták a tanárok és az iskolavezetök szakmai fejlödéséröl szóló következtetéseket. E dokumentum kimondja, hogy az Európai Unió tagországainak törekedniük kell arra, hogy minden frissen végzett tanár elegendö, tényleges támogatásban és iránymutatásban részesüljön pályafutása elején. Ennek érdekében a Tanács felkéri a tagállamokat, hogy biztositsák megfelelöen annak a lehetöségét, hogy minden kezdő tanár az első munkahelyén eltöltött néhány év során részt vegyen egy szakmai és személyes támogatást nyújtó bevezetö programban. A Tanács továbbá felkéri a Bizottságot, hogy lássa el gyakorlati információkkal a döntéshozókat a valamennyi kezdö tanárnak szóló strukturált bevezetö program létrehozásával kapcsolatban. Az Európai Bizottság által szervezett klaszter munka keretében, valamint e felkérésre válaszul elkészült a „Pályakezdö tanárok koherens és rendszer szintü bevezetö programjának kialakitsa - oktatáspolitikusok kézikönyve” címü dokumentum, melynek Bizottság általi kiadása folyamatban van. E tanulmány bemutatja a kézikönyv tartalmát és a szerzö személyes tapasztalatain keresztül a bevezetö támogatási rendszerröl való európai együttgondolkodást, a magyarországi bevezetés mérlegelésével együtt.
\end{abstract}

\section{Előzmények}

Magyarország 2008 óta vesz részt az Európai Bizottság által, a tagországok tanárképzéssel kapcsolatos szabályozásának nyílt koordinációjára létrehozott tematikus munkacsoport, a Tanárok és Oktatók Klaszter munkájában. A klaszter tevékenységét az egymástól való tanulási tevékenység ${ }^{1}$ (továbbiakban: PLA) képezi. A PLA lényege a nemzeti oktatási rendszerrel kapcsolatos egyfajta kritikus gondolkodás egy adott témakörben más tagországok szabályozási gyakorlatának megismerése által, kívánt eredménye a saját ország rendszerének újfajta közelítése és közös európai szintü javaslatok megfogalmazása.

\footnotetext{
${ }^{1}$ Egymástól tanulási tevékenység, angolul Peer Learning Activity, melynek használatos rövidítése
} a PLA. 
Észtországban Tallinn adott otthont 2008 októberében egy 11 tagország részvételével zajló bevezetéssel kapcsolatos PLA-nak ${ }^{2}$. A PLA célja olyan tanárképzési szabályozás, illetve oktatáspolitika feltárása volt, mely garantálja az új tanárok hatékony bevezetését a tanári szakmába. A PLA során magyar delegáltként alkalmam volt részt venni e közös gondolkodásban, és betekintést nyerni az észt, a ciprusi, a német és a skót bevezető támogatási rendszerbe ${ }^{3}$. A klaszter a több napos intenzív vita és megbeszélés eredményeit és javaslatait, egy beszámoló keretében nyújtotta be az Európai Bizottsághoz, mely a kiinduló pontját képezte a 2010 áprilisában az Európai Bizottság által kiadott jogalkotói kézikönyvnek. A következő rész a PLA-n közösen formált gondolatok és e kézikönyv föbb tartalmi elemeit ismerteti.

\section{A bevezető szakasz és a bevezető támogatási rendszer}

A PLA-n folytatott hosszas egyeztetés eredményeként a bevezető szakaszt (induction period) a tanári oklevél megszerzését követően, a tanári pálya indulásakor kezdődő egy-három évig tartó időszakként határoztuk meg. Ez a szakasz tehát akkor kezdődik, amikor a tanárképzés már sikeresen lezárult, a tanári oklevél birtokában a tanár elhelyezkedik és megkezdi munkáját első munkahelyén. A bevezetö szakasz során nyújtott támogatás a pályakezdö tanár karrierének elindulásához nyújtott támogatás.

A bevezető szakaszban támogatásra több okból is szükség van. Elsősorban azért, hogy elkerülhetö legyen a kezdeti nehézségek miatt a szakképzett tanárok pályaelhagyása, mely a képzés állami és személyes befektetésének elfecsérlése. Ez különösen fontos azon országok számára, amelyekben tanárhiány van akár egyes szakok vonatkozásában, akár általános tekintetben (European Commission, 2010). A tanári mesterség „kannibalizmusának” elkerülésén, illetve az államháztartási források felhasználásának hatékonyabbá tételén túl, a bevezető szakasz a tanári pálya elején végbemenő szocializációs folyamatok támogatása miatt is szükséges. A tanári oklevél megszerzését és az elhelyezkedést követő szakaszra esik a szakmai és az iskolai, intézményi szocializáció, valamint a tanári identitás megérlelődése, kiforrása is. E kritikus szakasz sikere elengedhetetlen a pályán maradáshoz, ezért szükséges a támogatás a pályakezdő tanár számára.

E szakaszban a támogatás akkor is szükséges, ha a pályakezdő egy minden mércével magas színvonalú és minőségü tanárképzési programban szerezte oklevelét. Ezt mi sem bizonyítja jobban, mint a vezető multinacionális nagyvállalatok hasonló gyakorlata. E cégek jellemzően a legjobb végzősök, az évfolyamelsők közül válogatnak, mégis szinte kivétel nélkül vállalati képzéssel fogadják a pályakezdő diplomásokat. A képzés során a cég filozófiáját, misszióját, müködésének alapelve-

\footnotetext{
${ }^{2}$ Lásd a Bizottság hivatalos klaszter honlapját: http://www.kslll.net/Default.cfm.

${ }^{3}$ Magyar delegált volt még: Falus Iván, egyetemi tanár, Eszterházy Károly Főiskola.
} 
it, a szokásokat és munkafolyamatokat, azon belül a konkrét munka elvégzésével kapcsolatos információkat, a szükséges speciális módszerek és eszközök használatát tanítják meg, miközben a munkavállaló megismeri a vele szemben támasztott konkrét elvárásokat és tőle elvárt értékrendet. Mindez a pályakezdő mielőbbi teljes értékü munkaerővé válását segíti azáltal, hogy biztosítja a vállalat-, és feladatspecifikus ismeretek megszerzését, vagyis az intézményi és szakmai szocializációt. Nincs olyan felsőoktatási képzési forma, mely ennyire konkrét felkészítést adhatna, és nem is lehet ez a felsőoktatási képzések célja.

Éppen így, a jól felkészült és kompetens pályakezdő tanár is intézményi és szakmai szocializációs folyamat révén válik teljes értékü tanárrá, anélkül sérülékeny, ezért biztosítani kell számára egy eredményes támogatási rendszert. A PLA során megfogalmazott és a Bizottság részére eljuttatott legfontosabb klaszter üzenet ennek megfelelően az volt, hogy a pályakezdő tanárok bevezetö támogatását jognak és kötelezettségnek kell tartanunk. Jognak, vagyis valamennyi pályakezdö tanár számára hozzáférhetőnek, illetve kötelezettségnek, vagyis valamennyi pályakezdő tanár kötelezettsége az ezen való részvétel. Ez az üzenet kapott aztán támogatást az Oktatási Bizottságon, majd az oktatási miniszterek informális, göteborgi értekezletén, és került be a Tanács következtetéseibe, mint a tagállamok kormányai részre történő felszólítás, hogy teremtsék meg valamennyi pályakezdő tanár számára a bevezető támogatási rendszerben való részvétel lehetőségét.

\section{A bevezető támogatás tartalma}

A PLA során áttekintett bevezető támogatási rendszerek alapvetően három területen nyújtanak a pályakezdő tanár számára támogatást. Az egyik a szakmai támogatás, vagyis a pályakezdő tanár szaktárgyi, oktatási és nevelési kérdésekben való segítése. A másik, ehhez szorosan kapcsolódó, a személyes támogatás, mely a saját tanári identitás kialakításának előmozdítását célozza. Ennek részét képezi az érzelmi támogatás is, mely a nehézségeken való sikeres túljutás képességének érzését erősíti. (A PLA keretében megkérdezett pályakezdő tanárok mindegyike a támogatások közül az érzelmi támogatást tartotta a legfontosabbnak.) A harmadik támogatás egyfajta közösségi beilleszkedés támogatása, vagyis az iskolai és szakmai közösségekbe való integráció segítése.

E háromféle támogatást, egy bevezető támogatási rendszer keretében több, egymás hatását erősítő alrendszer együttesen nyújtja. Ezek a mentorrendszer, a szakértői támogatási rendszer, a társak rendszere és az önelemzés rendszere.

A bevezető támogatás alapeleme, alaprendszere a mentorrendszer, mely egyrészt személyes, másrészt csoportos mentorálást is jelenthet. A mentorálás keretében a mentor széles eszközrendszerrel, például megfigyelés, naplózás, együtt tanítás és portfolió használatával nyújt visszajelzést a pályakezdőnek. E mentor a tanárképzési programok gyakorlatában szereplő mentorhoz - hazánkban a (gyakorlat)vezető 
tanárhoz - hasonlóan tapasztalt és kiváló tanár, aki a pályakezdő tanár mentorálása esetén hasonló szerepet tölt be: alapvetően visszajelez. Azonban itt a felek viszonyrendszere és emiatt a visszajelzés jellege is átalakul. Míg a tanárképzési gyakorlat során a vezető tanár egy hallgató képzését végzi, instruál, példát mutat, tevékenységet korrigál, véleményt alkot és részt vesz az értékelésben, addig a bevezető támogatásban a mentor és a pályakezdő kapcsolatrendszere mellérendelt, és a visszajelzés módja is ennek megfelelő: a mentor kérdésekkel, felvetésekkel segíti a pályakezdő tanár önálló döntéseit és tevékenységének önértékelését. A bevezető szakaszban a mentorálás során a felvetések és kérdések, az önelemzés kétirányú. A pályakezdő tanárral folytatott beszélgetésekböl, felvetésekből és új kezdeményezésekböl a mentor és az iskola is tanul, tanulhat. Összességében a mentor és a pályakezdő tanár egyenrangú felek, kapcsolatuk alapja a kölcsönös tisztelet és bizalom, célja elősegíteni a pályakezdő tanár önelemző, önfejlesztő munkáját.

A mentor további fontos szerepe az iskolai közösségbe érkező új kolléga segítése. A pályakezdő tanárnak a sikeres túléléshez meg kell ismerkednie az iskolai dokumentumokban rögzített pedagógiai programmal és Szervezeti és Működési Szabályzattal, valamint a kimondatlan szabályokkal, hagyományokkal, értékekkel, a szokásokkal, a tanárok, a diákok és a szülők közötti bonyolult viszonyrendszerrel, az iskola szerepével a helyi közösségben. De a mentor és a pályakezdő tanár viszonyrendszere itt sem egyirányú, tehát nem csak a mentortól a tanár felé irányul. Ezen a területen is a „friss szem”, menedzsment fogalommal élve a szervezeti vakságtól mentes újonnan érkező, nagyon hasznos javaslatokkal, újításokkal élhet, melyet egy jó mentor hatékonyan képes közvetíteni az iskolai közösség felé.

A bevezető támogatás egy másik lehetséges formája a mentor rendszeren túl a szakértői támogatás. Egyes kihívások a pályakezdő szakaszban a korábbi tapasztalatok alapján előreláthatók és jellemzőek, ilyen például a tanulók motiválása, a szülőkkel való kapcsolattartás, az osztálytermi fegyelmezés, vagy a heterogén tanulói csoportok kezelése. Ezek megválaszolásában hatékony és hatásos támogatás lehet pályakezdő tanárok csoportjai számára szakértők által tartott szeminárium, képzés, vagy nyomtatott, digitális vagy online támogató anyag. Ilyen szakértői támogatást nyújthat felsőoktatási intézmény, szakmai vagy szolgáltató szervezet.

További fontos támogatást jelenthet a társak rendszere, vagyis a pályakezdö tanárok informális vagy formális hálózata. A társak hasonló helyzetük megosztásával feloldhatják a problémákkal szembeni egyedüllét és elszigeteltség érzetét, az öszinte egymás közötti kommunikáció hozzájárulhat a helyzetek jobb megértéséhez, innovatív, konstruktív megoldási lehetőségek megtalálásához és végeredményben a pályakezdő tanár reálisabb önértékeléséhez. (A PLA során kérdezett hallgatók a társak szerepét igen nagyra értékelték az érzelmi támogatás nyújtásában.) A társak hálózatának egyik lehetséges formája a képzőhely által a végzett hallgatók számára nyújtott támogató szeminárium, vagy például internetes felület. A PLA-n bemutatott észt tapasztalatok szerint ez utóbbi azonban csak akkor képes 
betölteni a támogató jellegü közösségi funkciót, ha a pályakezdő tanárok az internetes közösségbe érkezés előtt személyesen is ismerték egymást. Elözetes személyes kapcsolat hiányában a tapasztalatok szerint a pályakezdők nem osztják meg egy internetes felületen személyes problémáikat társaikkal.

A bevezető támogatás sorrendben utolsóként említett, azonban tartalmilag legfontosabb eleme az önelemzés rendszere. A bevezető szakasz lényege, hogy a tanár a mindennapi tevékenységében megtalálja örömét, kibontsa önmagát, a tanári identitása kiforrjon, az önbizalma erősödjön, valamint a szocializációs folyamat által az iskolai és a szakmai közösség egyre elfogadottabb, aktívabb és építő részesévé váljon. Mindez a tanár egyéni hozzájárulása, aktivitása, önreflexiója nélkül elképzelhetetlen. A bevezető szakaszban nyújtott valamennyi támogatás a pályakezdő tanár önelemzését, önfejlesztését kell, hogy előmozdítsa, nem öltheti a kész recept, vagy a biztos tipp formáját. Az önelemzés és önfejlesztés központi és időigényes feladatára a pályakezdő tanárok óraterhelésének meghatározásakor fontos figyelemmel lenni.

Hatékony támogatás a fenti alrendszerek egymást erösitő, koherens egységként való müködésével biztositható. A személyes, a szakmai és a közösségi beilleszkedést célzó támogatás bármely alrendszer célja lehet. A mentor mindhárom támogatási formában kulcsszereplő kell, hogy legyen, a szakértők elsősorban a szakmai támogatásban játszanak szerepet, a társak bármelyik területen nyújthatnak fontos támogatást, az önelemzés, pedig az alapja mind a szakmai, mind a személyes fejlödésnek, illetve a közösségi beilleszkedésnek.

A bevezető szakasz során nyújtott támogatás színtere elsősorban az iskola, azonban jó, ha egy országos rendszer nem pusztán az iskolában a mentortól kapott támogatásra épít. Könnyen kialakulhat olyan helyzet, hogy a mentor és a pályakezdő tanár konfliktusba kerül, melynek megoldásában segítség lehet egy egyetemi vagy szakértői támogató szeminárium, vagy segélyvonal, vagy a társak rendszere. $\mathrm{Az}$ alrendszereket tehát szervezetten, egymás hatását erősítő módon célszerü országos rendszerré kovácsolni.

A bevezető támogatási rendszerrel kapcsolatban ugyancsak fontos kérdés, hogy értékeléssel vagy anélkül zárul. Míg egyes országokban a támogatási rendszer lényege az, hogy a tanár a pályán maradjon és sikeresen lássa el feladatát, addig más országokban e célkitüzés mellé minősítő értékelés is kapcsolódik. A minősítő értékeléssel záruló bevezető támogatási rendszer leginkább az angolszász világra jellemzö, ahol a tanári oklevél megszerzése automatikusan nem jogosít fel a közoktatásban tanári munkakör betöltésére. A tanári jogosultságot a bevezető szakasz sikeres lezárása után szerzi meg az egyén. Ez a rendszer a pályakezdő tanárt rákényszeríti a bevezető rendszerben való aktív részvételre, azonban kritikusok szerint a bevezető támogatási rendszert lezáró értékelés az, ami aláássa a mentor és pályakezdő tanár bizalmi viszonyát, és ezáltal korlátozza a támogatás valós értékét. Európai szinten mindkét modell elfogadott, mindkettő szisztémára található sikeresen müködő rendszer. 


\section{A bevezető támogatási rendszer perspektívái}

Az országos bevezető támogatási rendszer kialakításával és üzemeltetésével minőségi és mennyiségi változások is elérhetők, e perspektívákat kívánja bemutatni e fejezet.

Könnyü belátni, hogy amennyiben a tanárok pályaelhagyása a tanári pályára lépést követő években jelentős, ez a tanárképzésbe fektetett összegek jelentős részének makrogazdasági szintű elherdálását jelenti, valamint egyes szakok tekintetében, vagy általában is, tanárhiánnyal fenyegethet. Mindezek a negatív hatások csökkenthetők a bevezető támogatási rendszer kialakításával, üzemeltetésével.

A tanitás minőségének emelése is megfogalmazható hosszú távú célként a bevezető támogatási rendszer megteremtésekor. A tanárok első tantermi élményei kulcsfontosságúak, mert e szakaszban a tanár kész a tanulásra, kész munkamódszereinek megváltozatására és magasak az elvárásai önmagával és a rendszerrel szemben is. Ha a pályakezdő tanár megkapja a megfelelö támogatást, akkor nagyobb a valószínüsége, hogy a későbbiekben is eredményes lesz a tantermi tevékenysége (European Commission, 2010).

A bevezető támogatási rendszeren keresztül az iskolák szakmaisága is fejleszthető, hiszen támogatási rendszer hiányában a pályakezdő tanárok jellemzően arra törekszenek, hogy mielőbb belesimuljanak a tanári közösség normáiba, s ez gyakran együtt jár azzal, hogy innovatív ötleteik, javaslataik meg sem születnek vagy nem artikulálódnak. A bevezető támogatási rendszer biztosította iskolai mentorok kiemelt szerepet játszhatnak a javaslatok felszínre hozatalában és iskolai hasznosulásában, ezáltal az iskolák tanulószervezetté alakitásának elömozditásában.

A témához kapcsolódó személyes élményem, hogy a PLA egyik állomásaként ellátogattunk a Tallinntól nem messze lévő, Viimsi Kool nevü általános iskolába és gimnáziumba (www.viimsi.edu.ee). Az iskola egy teljesen új, folyamatosan épülö és dinamikusan növekvő városrész egyetlen iskolájaként az elmúlt években szinte példátlan növekedésen ment keresztül. A városrészbe település miatt a diákok létszáma 2005 óta évente több száz fővel nőtt, 2008-ban közel 500 fővel, látogatásunk idején a létszám már meghaladta az 1300-at. A tanárok létszáma 2006-ról 2008-ra 30 fővel növekedett. A tanári létszámnövekedés alapvetően pályakezdő tanárok felvételével teljesült, akiknek mindegyike az észt modell szerinti bevezetö támogatásban részesült. A látogatás során volt lehetőségünk pályakezdő tanárokkal és mentoraikkal is beszélgetni. E beszélgetések során a legmeglepőbb az új módszerek, ötletek, javaslatok felé való nyitottság volt, mely az iskolát, mint közösséget jellemezte. Mivel a tanári kar meghatározó része vagy mentorként vagy pályakezdő tanárként a tanári tevékenység folyamatos önelemzö, önfejlesztő gyakorlatát mindennapi szinten valósítja meg, ezért a teljes iskolai közösséget és kultúrát a konstruktív jobbító szándék, folyamatos fejlődés és lendület jellemzi. Számomra ez a kivételes iskola megmutatta, hogy normális körülmények között hosszú távon, a bevezető támogatás során szerzett pozitív tapasztalatok - és a tanári életpályát kísé- 
rő folyamatos szakmai fejlödés - milyen, a környezeti kihívásokhoz határtalanul rugalmasan és eredményesen alkalmazkodó iskolát képes teremteni.

Az iskola tanulószervezetté válásának előmozdításán kívül a bevezető szakasz fontos jellemzője, hogy sajátos helyzeténél fogva hidat képez a tanárképzési szakasz és a tanári pálya végéig tartó folyamatos szakmai fejlödés ${ }^{4}$ között. Az utóbbi kifejezés tükrözi azt az európai elvárást, hogy a tanári életpálya során az önelemzés, az önfejlesztés és a továbbképzések eredményeként valóban folyamatos szakmai fejlődés valósuljon meg. A PLA során megfogalmazott konklúziók között szerepelt, hogy a tanárképzési program, a bevezető támogatási rendszer és a folyamatos szakmai fejlődés mind szemléletben, mind szakmai tartalomban koherens egysége fontos szerepet játszik a tanári tevékenység megfelelő minőségének biztosításában. A bevezető szakasz a tanárképzési program sikeres befejezését követi, annak tartalmára és tapasztalataira épít, de egyben reflektív tanári attitüd kialakításával megalapozza a folyamatos szakmai fejlődést. Ezt a hármas egységet szimbolizálja az 1. ábra.

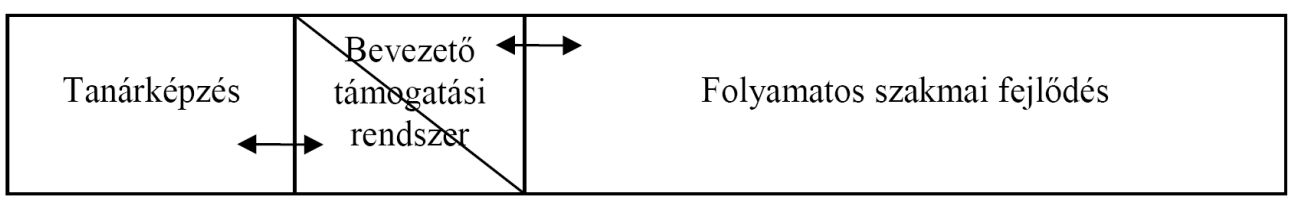

\section{1. ábra: A bevezető szakasz híd szerepe}

E hármas egységből adódnak a bevezető támogatási rendszer müködtetésének további perspektívái. A bevezető szakasz alatt nyújtott támogatási rendszer tapasztalatait elemezve objektív visszacsatolás nyújtható a tanárképzési szakaszról. Ez nagyban hozzájárulhat a tanárképzési forma és tartalom valós közoktatási igényeknek megfelelő folyamatos fejlesztéséhez.

A három szakasz koherenciájából következik, hogy a tanárképzési szakaszt követően a tanári pályán való elhelyezkedéssel a tanulási folyamat nem zárul le, csak más formát ölt. A bevezető szakasz keretében, a szakmai szocializáció elemeként az önelemző és az élethosszig tanuló tanár ideája és gyakorlata kialakítható a pályakezdőben. A tanári életpálya során elvárt szakmai fejlődés hatékonyan közvetíthető az egyes tanári életpálya szakaszokhoz rendelt kompetencia profilokkal, ezért a bevezető támogatási rendszer kialakításakor is szükséges és hasznos a szakasz végére elvárt tanári kompetencia szintek meghatározása. Ez elengedhetetlen,

\footnotetext{
${ }^{4}$ A Magyarországon tanártovábbképzésnek nevezett, tanári életpályát végigkísérő szakaszt az angolszász terminológia ,continuous professional develeopment” (CPD) folyamatos szakmai fejlődés elnevezéssel illeti. A folyamatos szakmai fejlődés elnevezés a szervezett tanártovábbképzéseken kívül a tanári tevékenységgel kapcsolatos önreflexiókat, önfejlesztést, az informális és nonformális tanulást is magában foglalja.
} 
ha a bevezető támogatás kompetencia szintekhez viszonyított minősítő értékeléssel zárul. A tanári képesítés megszerzéséhez szükséges kompetencia szintek, a bevezető szakasz végére elérendő kompetencia szintek együttesen előrevetítik és megalapozzák a tanárokkal szemben az egyes karrierszakaszokban támasztható elvárásokat.

\section{A sikeres bevezető rendszer kritériumai}

A PLA célrendszeréből - a tagországi szabályozás kritikus értékeléséből és lehetséges jobbításából - következően, a tallinni eszmecsere egyik központi kérdése annak a meghatározása volt, hogy milyen kritériumok teljesülése mellett lesz sikeres egy bevezető rendszer kialakítása és fenntartása. A teljesség igénye nélkül hét fö kritériumkört azonosítottunk. Ezek közül az elsö, a tanárképzés, a bevezetö rendszer és a folyamatos szakmai fejlödés egységessége, egy folyamattá építése, melyröl az előző rész végén már esett szó. E kritérium szerint a bevezetô támogatás akkor sikeres, ha a tanárképzés során szerzett kiinduló ismeret, készség, és kompetencia ${ }^{5}$ szintre - egyes országokban standardok formájában - figyelemmel van, arra épít, valamint ha a folyamatos szakmai fejlődésre és a reflektív tanári gyakorlatra készít fel.

A bevezető támogatási rendszer sikerének másik alapvető záloga a tiszta szerepkörök és felelösségi viszonyok megteremtése. Nemcsak a pályakezdő tanárral szemben támasztott elvárások és feladatok szorulnak azonosításra, hanem azon túl, a támogatási rendszer valamennyi szereplője - a mentor, az iskolavezető, az iskolai közösség, a minisztérium, az önkormányzat, a szakmai szervezetek, a felsőoktatási intézmények, az egyéb szervezetek - számára is egyértelmủvé szükséges tenni a rendszer által támasztott feladatköröket és a felelösségi viszonyokat. Ahhoz, hogy a pályakezdő tanár számára nyújtott támogatások koherens rendszert alkossanak, elöre rögzíteni kell, hogy egyes szereplők milyen támogatást milyen formában, kinek és mikor nyújtanak, van-e értékelés az egyes tevékenységek végén és ki végzi azt.

A szereplők azonosításán és az általuk nyújtott támogatási forma feladatain és ellátásán kívül a rendszerszerü müködéshez az is szükséges, hogy a szereplők között kölcsönös bizalmi viszony legyen. A bevezető szakasz lényege a tanári önfejlesztés és reflexió előmozdítása, ez bizalmi légkör nélkül nehezen elképzelhető. Külön említést érdemel a pályakezdő szocializációjának színteréül szolgáló iskola befogadó jellege, mert a sikeres bevezető szakasz záloga a támogató, tanulást előmozdító iskolai közösség és környezet.

A siker további kritériuma a szereplök kiváló minősége. Kulcstényező, hogy csak olyan valóban kiváló tanár váljon mentorrá, aki elsőrangú kommunikációs készséggel rendelkezik: értő füllel tudja meghallgatni a kezdő tanár problémáit, il-

\footnotetext{
${ }^{5}$ A Tanácsi következtetésekben és egyéb uniós dokumentumokban rendszerint a „knowledge, skills and competencies” vagyis az ,ismeretek, készségek és kompetenciák” megfogalmazás szerepel a képzések kimeneteli eredményének meghatározásakor. Sokan azonban a kompetencia fogalmába beletartozónak gondolják az ismereteket és a készségeket is.
} 
letve a pályakezdő számára nyújtott visszacsatolása mindig segítő szándékú, fejlesztő jellegü és önreflexiót gerjesztő.

$\mathrm{Az}$ iskola vezetőjének kiválósága is kulcstényezője a bevezető szakasz eredményességének. A jó közoktatási vezető érzékeny tanárainak fejlődésére és különböző igényeire, a tanulásban személyesen nyújt példát, törekszik inspiráló tanuló környezet kialakítására, valamint a kezdő tanárban lehetőséget lát az iskola számára. Az iskolavezető támogatása és a mentorba vetett bizalma mellett válhat valósággá a mentor hatékony szakmai, személyes és közösségi támogató munkája az iskolában. Az eredményes bevezető támogatási rendszer további feltétele, hogy a tanárképző intézmények is bizalommal, nyitottsággal és a legkiválóbb szakemberek részvételével kapcsolódjanak a bevezető támogatási rendszerhez. A képzőhelyek hajlandósága és képessége a közoktatási intézményekkel való együttmüködésre lehet az alapja az iskolák tanárképzési programokról való őszinte és reális visszajelzésének, valamint a tanárképzési programok bevezetési tapasztalatok szerinti módosításának.

Egy sikeres bevezető támogatási rendszer további, alapvető jellemvonása a szereplők számára nyújtott megfelelö pénzügyi támogatás és egyéb elismerés. A rendszer valós müködéséhez elengedhetetlen, hogy a pályakezdő tanár megfelelö bért kapjon, és csökkentett óramennyiségben tanítson. A bérszínvonal alapvetően és pozitív irányba befolyásolja a tanári pálya presztízsét, így a tanárképzésre jelentkezők számát is, valamint a pályán maradás vonzerejét. A csökkentett óraszám pedig ahhoz szükséges, hogy a pályakezdő tanár számára álljon rendelkezésre megfelelő mennyiségü idő a bevezető programban való aktivitásra: szakmai szemináriumon való részvételre, mentorral való beszélgetésekre, önelemzésre, tantermi kísérletezésre, önfejlesztésre, társakkal való megbeszélésekre. Hasonló módon fontos, hogy a mentor, a szakmai, személyes és közösségi támogatásért díjazást kapjon, illetve óraterhelése ne legyen magas, hogy munkaidejébe a pályakezdő tanár órájának látogatása, vele való érdemi diskurzus beleférjen. Megfelelő pénzügyi eröforrások szükségesek továbbá valamennyi támogató tevékenység kialakításához, megszervezéséhez és megfelelő színvonalú biztositásához. Így forrást kell biztosítani az iskolának a befogadó, támogató környezet előmozdítására, országos vagy képzőhelyi szinten a társak rendszerének kiépítésére, szakemberek, szakmai fórumok, szemináriumok biztosítására.

A bevezető támogatások összességének rendszerszerü müködéséhez, illetve ahhoz, hogy valamennyi pályakezdő tanár jogosultsága és kötelezettsége legyen a bevezető programon való részvétel, szükség van megfelelő minőségbiztositás kialakitására. A bevezető támogatási rendszer tervezésekor a rendszer részeként szükséges a valamennyi támogatási formára kiterjedő minőségbiztosítási rendszer megtervezése. A bevezető szakaszban országosan egységes standardok mentén kell az önelemzés, önfejlesztés minőség biztosításáról gondoskodni, így szükséges a mentor rendszerre, a szakértői rendszerre, a társak támogató rendszerére vonatkozó egységes és szigorú monitoring rendszert is kialakítani. Fontos, hogy a monitoring 
rendszerből nyert adatokat elemezzék és a szereplők számára rendszeres visszajelzést nyújtsanak. A minőségbiztosítási rendszer pedig akkor igazán hasznos és előrevivő, ha a szereplők elkötelezettek a rendszer és annak fejlesztése mellett, aminek alapja a korábban már említett szereplök közötti bizalom és a szereplök megfelelő pénzügyi díjazása, elismerése.

\section{Európai kitekintés}

Európában a bevezető támogatási rendszer értelmezése, megvalósulási formája színes képet mutat. Az országok közel felében létezik bevezető támogatás valamilyen formában, de csak az országok szük körében müködik több támogatási forma rendszerszerü egységeként. A bevezető támogatás értelmezése is változatos a releváns időszak tekintetében, a támogatások megvalósuló formájában, az érintett szereplők, úgynevezett stakeholderek által ellátott feladatok és felelősségek megosztásában, valamint abban, hogy a bevezető szakasz végén szükségesnek, hasznosnak érzik-e a minősítő értékelést. További eltérés lehet, hogy a bevezető szakasz egyes országokban elsősorban a pályakezdő tanár pályán maradását, szakmai támogatását kívánja megvalósítani, míg más országokban ez a tanári pályán végignyúló szakmai standardok elérésének egy lépcsőfoka, teljesítésük a pályán való aktív tevékenység előfeltétele.

A bevezető szakaszról Európában jelenleg két forrásból lehet információkat találni, az Eurydice Kulcsadatok az oktatásról 2009-es kiadásából, valamint a Tanárok és Oktatók Klaszter bevezető szakaszról készült kézikönyvéből.

Az Eurydice kiadvány a bevezető támogatási rendszert a tanárképzés utáni kötelező jellegü, támogató és ellenőrző tevékenységek szakaszaként definiálja, ahol a pályakezdő tanár teljes értékü tanári szakképzettséggel (jogosultsággal) még nem rendelkezik. Az Euridyce definíciója megengedi, hogy e szakasz a tanárképzés záró fázisa legyen, ugyanakkor munkahelyi szakképesítő szakaszként (on the job qualifying phase) nevezi meg. A klaszterben a PLA keretében folytatott vita végén sikerült egyetértésre jutni arról, hogy a bevezető szakasz nem lehet a tanárképzés része, mert már megszerzett oklevélre építve a tanár munkahelyi és szakmai szocializációját segíti elő. E célrendszer pedig nem fér össze azzal, hogy ez a szakasz a tanárképzés része legyen. Ilyen értelemben tehát a klaszter definíciója szigorúbb, mint az Eurydice-é.

$\mathrm{Az}$ áprilisban kiadott, bevezetéssel kapcsolatos kézikönyv a bevezető támogatás definíciója terén leírja, hogy a nemzeti „hivatalos” definíciók eltérőek. Egyes országokban a bevezető támogatási rendszer a már oklevelet és tanári jogosultságot szerzettek számára nyújt támogatást, más országokban az oklevél megszerzése után, de a tanári jogosultság megszerzése elött állók részére, míg az országok harmadik csoportjában a tanári oklevél és a tanári jogosultság megszerzése előtt állóknak, de ezekben az esetekben a tanárképzés és a bevezető szakasz összemosódik. 
Az Euidyce definíciója alapján tizenegy európai országban nyújtanak szervezetten valamiféle bevezető támogatási rendszert, ezek: Ausztria, Egyesült Királyság (Anglia, Wales, Észak-Írország), Egyesült Királyság (Skócia), Észtország, Írország, Franciaország, Luxemburg, Portugália, Szlovénia, Törökország. Ezekben az országokban bevezetett rendszerek eltérőek a bevezető szakasz hossza, a nyújtott támogatási formák, az értékelés tekintetében, valamint abból a szempontból, hogy a bevezetô támogatás a tanárképzés részeként kerül-e értelmezésre. E tizenegy országból hétben nemcsak az általános iskolai tanárok képzését, hanem az óvó-, a tanító-, és a gimnáziumi tanárok képzését is követi támogatási rendszer. A bevezető támogatás hossza jellemzően egy év, de Szlovéniában csak tíz hónap, Németországban két év, legfeljebb két év Luxemburgban, Skóciában és Törökországban.

Az európai helyzetkép reális bemutatásához a kézikönyv szerzői egy rövid felmérést végeztek a klaszter tagok között a tagországi gyakorlatról, valamint felhasználták az Eurydice rendelkezésre álló adatait is. Az 1. táblázat tartalmazza a kézikönyv által publikált adatokat.

1. táblázat: A bevezető támogatási rendszer jellemzői az európai országokban

\begin{tabular}{|c|c|c|c|c|}
\hline \multicolumn{5}{|c|}{ Bevezetö támogatási rendszer az ISCED 1, 2, 3 szinteken tanitó tanárok számára* } \\
\hline \multirow[b]{2}{*}{ Ország } & \multicolumn{4}{|c|}{ országos szintü bevezetö támogatási rendszer } \\
\hline & nincs & $\begin{array}{l}\text { tanári oklevéllel } \\
\text { és jogosultsággal } \\
\text { rendelkezöknek } \\
\text { nyújtják }\end{array}$ & $\begin{array}{l}\text { tanári oklevéllel } \\
\text { rendelkezöknek } \\
\text { nyújtják, akik } \\
\text { nem rendelkeznek } \\
\text { tanári } \\
\text { jogosultsággal } \\
\end{array}$ & $\begin{array}{c}\text { sem tanári } \\
\text { oklevéllel, } \\
\text { sem tanári } \\
\text { jogosultsággal } \\
\text { nem rendelkezöknek } \\
\text { nyújtják } \\
\end{array}$ \\
\hline Ausztria & & & $\cdot$ & \\
\hline Belgium & $\cdot$ & & & \\
\hline Bulgária & $\cdot$ & & & \\
\hline Ciprus & & • & & \\
\hline Csehország & - & & & \\
\hline Dánia & • & & & \\
\hline $\begin{array}{l}\text { Egyesült } \\
\text { Királyság }\end{array}$ & & & • & \\
\hline Észtország & & • & & \\
\hline Finnország & - & & & \\
\hline Franciaország & & & & • \\
\hline Görögország & $(\bullet)$ & & & \\
\hline
\end{tabular}




\begin{tabular}{|c|c|c|c|c|}
\hline \multicolumn{5}{|c|}{ Bevezetö támogatási rendszer az ISCED 1, 2, 3 szinteken tanitó tanárok számára* } \\
\hline \multirow[b]{2}{*}{ Ország } & \multicolumn{4}{|c|}{ országos szintü bevezetö támogatási rendszer } \\
\hline & nincs & $\begin{array}{c}\text { tanári oklevéllel } \\
\text { és jogosultsággal } \\
\text { rendelkezőknek } \\
\text { nyújtják }\end{array}$ & $\begin{array}{l}\text { tanári oklevéllel } \\
\text { rendelkezöknek } \\
\text { nyújtják, akik } \\
\text { nem rendelkeznek } \\
\text { tanári } \\
\text { jogosultsággal }\end{array}$ & \begin{tabular}{|c} 
sem tanári \\
oklevéllel, \\
sem tanári \\
jogosultsággal \\
nem rendelkezöknek \\
nyújtják
\end{tabular} \\
\hline Hollandia & $(\bullet)$ & & & \\
\hline Írország & $(\bullet)$ & & & \\
\hline Lengyelország & • & & & \\
\hline Lettország & • & & & \\
\hline Litvánia & • & & & \\
\hline Luxemburg & & & & $\bullet$ \\
\hline Magyarország & $\bullet$ & & & \\
\hline Málta & • & & & \\
\hline Németország & & & $\bullet$ & \\
\hline Olaszország & • & & & \\
\hline Portugália & & & $\bullet$ & \\
\hline Románia & - & & & \\
\hline Spanyolország & $\bullet$ & & & \\
\hline Svédország & $\bullet$ & & & \\
\hline Szlovákia & $\bullet$ & & & \\
\hline Szlovénia & & $\bullet$ & & \\
\hline + Izland & $\bullet$ & & & \\
\hline + Lichtenstein & - & & & \\
\hline + Norvégia & $(\bullet)$ & & & \\
\hline + Törökország & & & $\bullet$ & \\
\hline
\end{tabular}

* Forrás: Európai Bizottság, 2010.

$(\bullet)$ : pilot projekt jelleggel került bevezető támogatási rendszer bevezetésre

Elmondható tehát, hogy viszonylag kevés európai országban működik koherens, országos rendszerré szervezett támogatás. Azonban több országban müködnek rendszerré nem szervezett támogatási formák, melyeket a pályakezdő tanár igény szerint hozzájuthat. A Kulcsadatok az oktatásról kötet szerint 20 európai ország nyújt valamilyen formában a pályakezdő tanároknak támogatást. A pályakezdő tanárok számára nyújtott támogatások formáit tartalmazza összegyüjtve a 2. táblázat. 


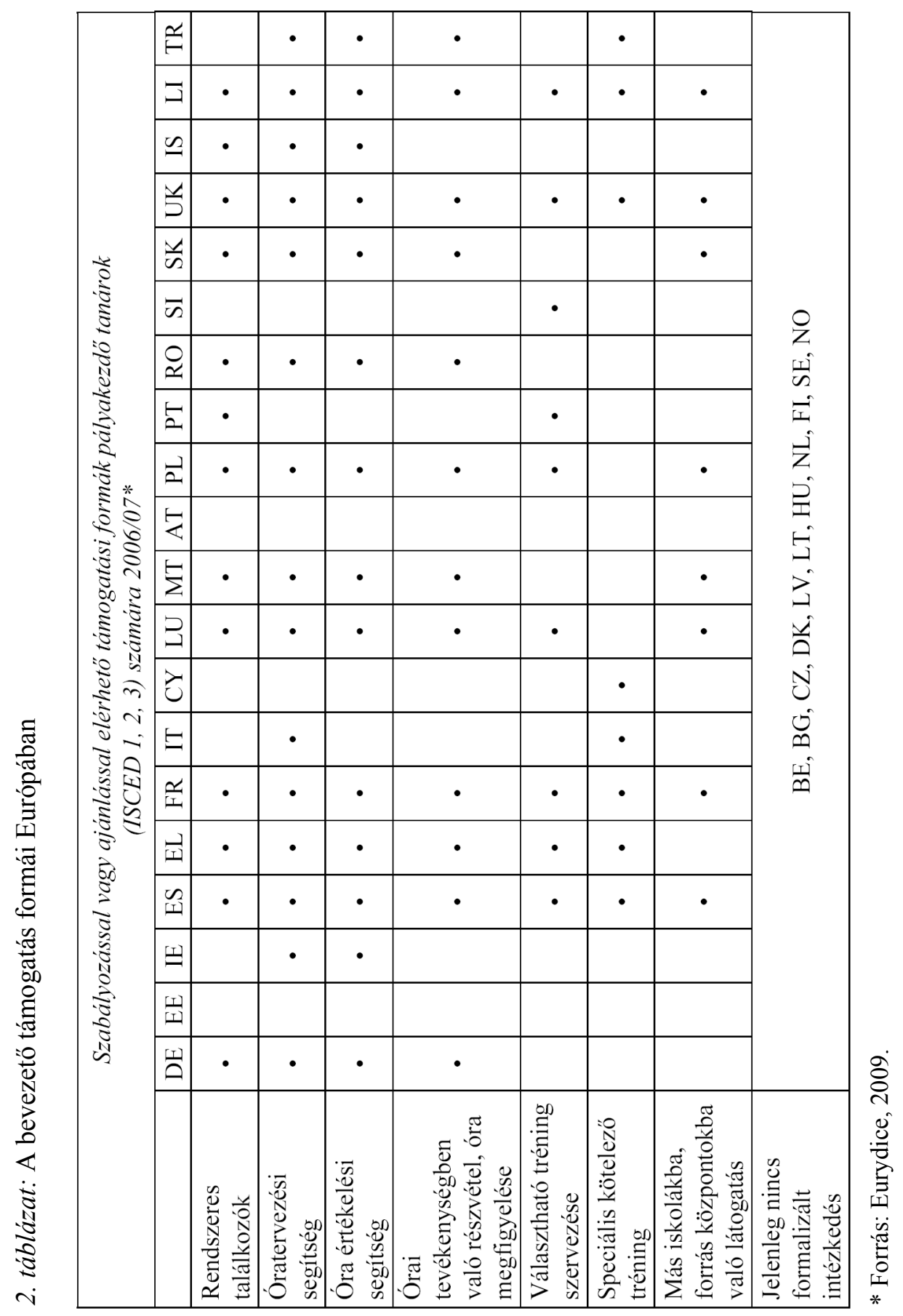


A következő részben a PLA során bemutatott négy országos rendszer, az észt, a ciprusi, a skót és a német közül két modell a skót és az észt bemutatására kerül sor.

\section{A skót modell}

A skót bevezető támogatási rendszert a súlyos tanárhiány miatt, valamint a pályaelhagyás csökkentése érdekében a közoktatásért felelős önkormányzatok megbízásából fejlesztették ki. A rendszert kialakító, majd annak módosításán dolgozó szakértői csoport javaslata alapján, széles körü társadalmi egyeztetés és egyetértés után került sor a rendszer bevezetésre, majd 2002. augusztus 1-én a módosítására. ${ }^{6}$

A jelenlegi szabályozás valamennyi pályakezdő tanár részére kötelezővé teszi a bevezető támogatási rendszerben való részvételt. Az egy éves támogatási rendszer alapja a folyamatos szakmai fejlődésre való felkészülés és az önelemzés. A „próbaidős tanárnak” (probational) négy fö témakör 23 területén kell tudni igazolni, hogy kompetenciáit a meghatározott standardok szintjére hozta ahhoz, hogy a bevezető szakasz végén a tanári jogosultságot megszerezze.

Öt különböző szintủ támogatási rendszer segíti ebben a pályakezdő tanárt. A skót állami támogatási szint az első, mely biztosítja a pályakezdő számára, hogy 35 órás munkahéten, legfeljebb heti 16 kontaktórával tanítson, hogy fizetett munkaidejéből heti 3,5 órát fordíthasson mentorral történő egyeztetésre, 6,5 órát pedig önelemzésre. Az állami, önkormányzati támogatás keretében biztosított továbbá, hogy a pályakezdő olyan településen kapjon munkát, mely a saját kérésének és a helyi tanárigénynek egyaránt megfelel. A pályakezdő külön hatezer fontos támogatásban részesül, ha Skócia ritkán lakott északi részét választja elhelyezkedésre.

A támogatási rendszer második szintjét a General Teaching Council of Scotland, vagyis a Skót Általános Tanári Tanács biztosítja. A Tanács a próbaidős, tehát tanári végzettséggel rendelkező és bevezető szakaszban részt vevő, valamint a tanári jogosultsággal rendelkező személyek nyilvántartásáért és a tanárok elhelyezkedéséért felelős szakmai szerv. A Tanács telefonos hotline vonallal, illetve szakértői támogatással áll a pályakezdő rendelkezésére, továbbá a standardok és profilok kialakításáért és karbantartásért, valamint a rendszer szintű minőségbiztosításért felel.

A helyi önkormányzat biztosítja a harmadik támogatási alrendszert ún. „bevezető menedzserek" (induction manager) révén. A bevezető menedzser feladata az oktatással kapcsolatos hírekről való tájékoztatás, az önkormányzat területén munkát vállaló pályakezdő tanárok számára találkozók szervezése havi rendszeresség-

\footnotetext{
${ }^{6}$ További információk találhatók a skót bevezető támogatási rendszerről a PLA honlapján található, Teacher Induction in Scotland címü prezentációból: http://www.tlu.ee/?LangID=1\&CatID=3496\&ArtID=2735\&action=article, valamint a skót bevezető szakasz hivatalos honlapján: http://www.gtcs.org.uk/Research_/publishedresearch_/TeacherInductionSchemeResearch/ research_teacher_induction_scheme.aspx
} 
gel, a pályakezdők és a bevezető támogatási rendszerből frissen kikerültek között egy támogató társrendszer kialakítása, általában véve az iskolai beilleszkedés támogatása, valamint a mentorképzés.

A negyedik támogatási szint a mentorrendszer (system of supporters), melyben a mentor feladata, hogy segítse a pályakezdő egyéni fejlesztési tervének kialakítását és az e szerinti célok teljesülését, látogassa óráit, tartson heti megbeszéléseket a pályakezdővel, nyújtson számára személyes és közösségi beilleszkedést elősegítő támogatást, valamint készítsen a pályakezdőről időszaki és év végi értékelő profilt.

A bevezető támogatási rendszer ötödik alrendszere a pályakezdő önálló munkája. Ö szervezi a mentorral való heti megbeszéléseket, dolgozik a személyes profilján, részt vesz a pályakezdők számára szervezett képzéseken, találkozókon, tantermi kísérleteket végez, folyamatos önelemzésével fejleszti a tevékenységét.

Összességében elmondható, hogy a skót modellben a kezdeményező, húzó szerep a helyi önkormányzatoké, az ellenőrző szerepet a tanárok szakmai szervezete, a Tanács látja el. A rendszer erősen formalizált és ezzel együtt költséges, fontos jellemzője, hogy társadalmi egyetértésen és hosszas egyeztető, finomító lépések folyamatán keresztül nyerte el mai formáját. E rendszerben a felsőoktatási intézmények szinte egyáltalán nem játszanak szerepet.

A skót bevezető támogatási rendszerben a pályakezdőt kompetencia profilok alapján negyedévente értékelik, majd a periódus egy minősítő értékeléssel zárul, melynek eredményeként a próbaidős tanár elnyerheti a tanári jogosultságot. A teljes rendszer hatékony működését monitoring és értékelö rendszer szolgálja. Jelenleg a bevezető szakasszal kapcsolatban felmerülő egyetlen kritika, hogy elrugaszkodott a valóságtól, mert a pályakezdő tanárok óraterhelése túl alacsony, ezért nem készíti fel őket megfelelően a tanársággal járó megterhelésre.

\section{Az észt modell}

Az észt modell sok szempontból a skót modell ellentéte. ${ }^{7}$ Az észt bevezető támogatási rendszer kialakításában és müködtetésében a központi és kezdeményező szerepet a tanárképző felsőoktatási intézmények játszák, míg a skót rendszerben a felsőoktatásnak alig van szerepe. Másik ellentétes jegye a skót rendszerrel összehasonlítva, hogy nagyon kevéssé szabályozott, gyakorlatilag a felsőoktatási törvény egy, a bevezető támogatást lehetővé tevő sora az a forma, amiben a kérdés szabályozása kimerül. A két tanárképző és tanártovábbképző felsőoktatási intézmény számára a közoktatás, a felsőoktatás és a minisztérium közötti szoros együttmüködés és a fejlesztésekben játszott eddigi kezdeményező szerepe nyújtotta a lehetőséget arra,

\footnotetext{
${ }^{7}$ További információk találhatók az észt bevezető támogatási rendszerről a PLA honlapján található, Induction and Teacher's Professional Development: the Estonian Project címü prezentációból: http://www.tlu.ee/?LangID=1\&CatID=3496\&ArtID=2735\&action=article
} 
hogy a meglévő meglehetősen tág törvényi szabályozással élve kezdeményezzék a bevezető támogatási rendszer kialakítását.

Az észt támogatási program a skóthoz hasonlóan egy éves, viszont nem kötelező. A pozitív tapasztalatok miatt mégis valamennyi végzős hallgató részt vesz e támogatási formában. A támogatási rendszernek három alrendszere van. Az egyetemeknél müködnek a bevezető központok (induction centers), melyek a mentorképzést végzik, támogató programokat és kísérő szemináriumokat szerveznek a pályakezdőknek, internetes alapú támogató anyagokat szolgáltatnak, valamint az országos bevezető rendszer folyamatos felügyeletét és fejlesztését látják el a minisztériummal együttmüködésben. Az egyetemi támogató szemináriumok csoportos összejövetelek, melyek föként iskolaszüneti napokon kerülnek megrendezésre, és tipikus, és/vagy konkrét problémák elemzésével és a megoldási lehetőségek megvitatásával kívánják a pályakezdők önelemzését, önfejlesztését segíteni.

Az egyetemi támogatás további eleme a társak rendszere, melyben az egy évfolyamról kikerülő pályakezdők egy közös nyári tréning után internetes felületen és igény szerint személyes találkozókon is kapcsolatot tartanak. A korábbi évek tapasztalatai azt mutatták, hogy a nyári közös tréning nélkül internetes kapcsolatba került pályakezdők között a személyes támogatás mértéke nem bizonyult megfelelőnek, ezért került bevezetésre a munkába állást megelőző nyári tréning.

A bevezető támogatási rendszer második alrendszere a már több fejezetben is leírt mentorrendszer. Az észt modellben a mentor a pályakezdő önelemzését és önfejlesztését támogató személy, aki azonban nem értékel, szerepe pusztán a támogatás. A skót rendszertől eltérően nem kompetencia-standardokra és konkrét szintelvárásokra készít fel, hanem a személyes és szakmai szocializáció elömozdítója megfigyelés és személyes konzultációk által.

Az észt bevezető támogatási rendszer alapja is a pályakezdő tanár önértékelése, önfejlesztése, így ez az országos rendszer harmadik pillére.

Az alrendszerek között az egyetemek vezető szerepe abból a megközelítésböl adódott, amely szerint a lehetséges szereplők közül ők látják világosabban a tanárképzés tartalmát, ezért azokat a nehézségeket is, melyekkel egy pályakezdő tanárnak szembe kell nézni, valamint ők a felhasználói, érdekeltjei azoknak a tapasztalatoknak, melyek a bevezető szakasz során szerezhetők a tanárképzésről. Az egyetemek domináns szerepének további előnye, hogy a pályakezdő tanár nem minden információt akar adott esetben a mentorával megosztani, egyes érzéseit, információit inkább a képzőhelyével egyeztet előbb, vagy a társaival osztja meg. Ez a rendszer viszonylag nagy egyensúlyt biztosít a mentor, a társak és az egyetemi szakértők segítsége között.

Az elmúlt évek tapasztalatai azt mutatják, hogy nehézséget okoz, hogy a pályakezdő tanárok és a mentorok óraterhelése a társkollegáikkal megegyezö, így sokszor nem marad idő a megfelelően elmélyült önelemzésre, vagy a mentorral folytatott beszélgetésre. További tapasztalat, hogy a mentornak nem elég, ha kiváló 
tanár. Fontos, hogy ne kész megoldásokra tanítsa a pályakezdőt, hanem támogassa a pályakezdő önelemző, önfejlesztő tevékenységét, felelősség érzetét, ezért felmerült, hogy a mentorképzésben e felkészítés nagyobb hangsúlyt kapjon. Általánosan is elmondható, hogy a tapasztalatok elemzése és értékelése alapján a bevezető támogatási rendszer folyamatos fejlesztése Észtországban is kitüzött cél.

\section{Összegzés és egy magyar program lehetőségei}

A pályakezdő tanárok számára nyújtandó támogatás 2009. november 26-a óta egy európai szintéren kitüzött, és tagállami szinten megvalósítandó feladat, melynek megvalósítása érdekében Magyarországnak is lépéseket kell tenni.

Magyarországon éppúgy, mint az európai tagállamok zömében most zajlik a tanárképzést is érintő bolognai reform megvalósítása. A tanárképzés magyarországi tartalmi és formai megújulása a szabályozás szintjén lezajlott, az új képzés bevezetése 2009 őszén, az első alapképzésben végzett évfolyam mesterképzésbe való belépésével megkezdődött. Ebből az a logikus lehetőség adódik, hogy a bevezető támogatási rendszert e képzés felfutásakor, az első végzős évfolyam oklevél szerzését követően indítsuk, vagyis 2012 tavaszán.

A tanári mesterszakon végzetteknek nyújtott bevezető támogatási rendszer lehetőséget teremthetne arra, hogy rendszerszerü és a „felhasználó”, vagyis a közoktatás szempontjai szerinti elemzést és értékelést kapjunk a tanári mesterszak müködéséröl és hatékonyságáról. A bevezetett tanári mesterszak felfutását és első évfolyamait követően fontos, hogy széles körü és valós monitoring mutatók álljanak rendelkezésre a képzés hatékonyságáról, eredményességéröl. A bevezető támogatási rendszer ezek közül talán a legreálisabb visszajelzésre képes. A 2012-es bevezetés pedig a bevezető szakasz végére elérendő kompetencia szintek meghatározása esetén megalapozhatná a tanári életpálya szakaszokhoz köthető tanári kompetencia szintek és standardok meghatározásának távlati munkáját is.

Az előzőekben bemutatott konkrét európai példák jól mutatják, hogy a bevezető támogatási rendszer a szereplök tanári szereppel kapcsolatos közös elvárásain alapul és kialakításuk egyszerre alulról és felülről jövő kezdeményezéshez kötődhet. A minisztériumok szabályozó vagy szabályzásban lehetőséget adó és a gyakorlatot támogató müködése nélkül, valamint további pénzügyi források bevonása nélkül egy bevezetö támogatási rendszer kialakítása és üzemeltetése nem képzelhetö el. Éppen így a szereplők, stakeholderek aktív szerepvállalása és kezdeményező fellépése nélkül sem. Mindezért fontos, hogy a hazai szakmai közélet is foglalkozzon a bevezetés kérdésével, alakuljon ki egy közös gondolkodás.

Az elöző oldalakon több pontban is kitértem arra, hogy a tanári mesterszakot záró fél éves összefüggő szakmai gyakorlat és a bevezető szakasz nem azonos, és nem összevonható. A gyakorlat során a tanárjelölt diákként szerzi meg az alapvető tanári ismereteket, késségeket, jártasságokat, a bevezető szakaszban pedig tanár- 
ként első munkahelyén fejleszti tanári identitását, fontos szakmai, közösségi szocializációs folyamaton megy át. Mindemellett a tanári mesterszak gyakorlati félévével kapcsolatos munkacsoport keretében végzett közös gondolkodás és az azt követő országos vita elindított egy folyamatot, valamint ráirányította a figyelmet a közoktatás és tanárképzés partnerségére. Fontos lenne e folyamat folytatása, fókuszban tartva a bevezető szakaszt és annak keretében a közelmúltban kialakított első hazai bevezető támogatási alrendszerként értelmezhető - szakmai segítő rendszer továbbfejlesztését.

2007. szeptember 1-töl került bevezetésre ${ }^{8}$ a közoktatásban dolgozó tanárok esetében is a gyakornok státusz. A szabályozás értelmében az állami fenntartású közoktatási intézményekben pályakezdő tanár határozatlan idejű kinevezése esetén az első három évben csak gyakornoki státuszban alkalmazható. A gyakornoki időszak végén a közoktatási intézmény gyakornoki szabályzatában meghatározott szakmai követelmények alapján a munkáltató „megfelelt”, illetve „nem megfelelt” minősítéssel értékel. Előbbi esetben a gyakornok határozatlan idejü közalkalmazottá válik, míg utóbbi esetben jogviszonya megszünik. A gyakornok szakmai követelményei két részböl állnak: az általános és a munkakörhöz kapcsolódó követelményekből. Az általános követelményeknek biztosítaniuk kell, hogy a gyakornok megismerje az intézmény nevelési programját, pedagógiai programját, szervezeti és működési szabályzatát, házirendjét, minőségirányítási programját, kollektív szerződését, az intézmény pedagógiai célkitüzéseit, azok gyakorlati megvalósulását, a gyermekek, a tanulók, a szülők, a pedagógusok jogait és kötelezettségeit, a fenntartói irányítással kapcsolatos általános rendelkezéseket, valamint a tanügyigazgatási dokumentumok alkalmazását. A gyakornok számára a törvény egy szakmai segítő támogatását biztosítja, akinek feladata a gyakornok tevékenységének figyelemmel kísérése, a gyakornoki követelmények teljesítésének segítése, a gyakornok félévenkénti értékelése. A szakmai segítő tevékenységéért kereset-kiegészítést kap, a gyakornokok számára pedig az óraterhelés felső határa a heti kötelező óraszámban került meghatározásra.

A fenti szabályozás egy reményteli első lépésnek tekinthető a bevezető támogatási rendszer felé, azonban jelen formájában inkább a közoktatási intézmény számára nyújt lehetőséget arra, hogy a nem megfelelően teljesítő pályakezdőtől munkaügyi szempontból egyszerủen meg tudjon válni, mint hogy a pályakezdő tanár számára nyújtson támogatást. A jelen szabályozás támogatási rendszernek több szempont miatt sem tekinthető. Egyrészt a gyakornok státusz nem valamennyi tanárra vonatkozik, hanem pusztán a határozatlan időre kinevezendő közalkalmazotti tanárokra, másrészt a gyakornok számára meghatározott rendeleti követelmények

\footnotetext{
${ }^{8}$ A közalkalmazottak jogállásáról szóló 1992. évi XXXIII tv. módosítása, valamint a 138/1992. korm. rendelet a közalkalmazottak jogállásáról szóló törvény végrehajtásáról a közoktatási intézményekben 4.A §-a alapján.
} 
nem tükrözik a személyes, szakmai és közösségi szocializáció valamennyi aspektusát, harmadrészt a gyakornok számára a szakmai segitő által nyújtott támogatás minősége nem biztosított, hiszen a szakmai segítő személye nem definiált, feladatait képzés és minőségbiztosítás kényszere nélkül végzi. A szabályozás további problémája, hogy a bevezető szakaszban nyújtott támogatás nem tüzi ki célul a pályakezdő számára a saját tevékenységének folyamatos elemzését és fejlesztését, rendszer szinten nem épül szervesen a tanárképzési tartalmakra, és nem célozza a folyamatos szakmai fejlődésre való felkészítést, így stratégiai célját sem tudja betölteni.

Mindezért a meglévő támogatási forma bevezető támogatási rendszerré szervezése továbbra is feladatunk. Magyarországon jelenleg nincs tanárhiány, az önkormányzati szerkezet erösen tagolt és alulfinanszírozott, ezért nem várható, hogy az önkormányzatok a bevezető szakasz hazai kezdeményezőiként lépjenek fel. A skót modellhez hasonlóan szabályozott és nemcsak folyamatában, de szervezeteiben is formalizált magyar bevezető támogatási rendszerhez a hazai költségvetési források és a kialakításhoz szükséges több évtizedes idő sem áll reálisan rendelkezésre. A magyar adottságokhoz mérten reálisabbnak tünik egy észt modellhez hasonló rendszer kialakítása. Ehhez azonban a felsőoktatási oldal szerepvállalási hajlandósága és a rendszer szintü elvárások egységesítésének képessége szükséges.

Feltételezve, hogy a magyar tanárképző felsőoktatás e feltételeknek eleget kíván és képes tenni, elképzelhető megoldási lehetőség a 2009 őszén elindult TÁMOP pályázatok keretében létrejövő Pedagógusképzési Regionális Kutató és Szolgáltató Központok szervezetére támaszkodni és a következő pályázati körében számukra lehetővé tenni bevezető támogatási rendszerek kialakításával és koordinációjával kapcsolatos feladatok ellátását. E regionális központok számára a jelenleg folyó pályázatban meghatározott feladatkörök - a tanári mesterszak gyakorlatának, valamint a tanár továbbképzések a koordinációja, a tanári mesterszak értékelése, a gyakorlatokhoz a mentorképzés, a pedagógusképzéssel kapcsolatos kutatások és szolgáltatások nyújtása - alapvetően hasonlítanak a bevezető támogatási rendszer észt modelljében bemutatott felsőoktatási bevezetési centrumok által végzett feladatokhoz, ezért a központokban szakmailag megnyugtató színvonalon és költséghatékonyan lehetne a bevezető támogatási rendszer szakmai koordinációját megvalósítani.

\section{Irodalom}

A közalkalmazottak jogállásáról szóló 1992. évi XXXIII törvény. http://www.kozszolga.hu/kozalkalmazotti_torveny

A 138/1992. korm. rendelet a közalkalmazottak jogállásáról szóló törvény végrehajtásáról a közoktatási intézményekben. http://www.magyarorszag.hu

Európai Bizottság (2009): A Tanács következtetései a tanárok és az iskolavezetők szakmai fejlödéséröl. 2009. november 26. Brüsszel.

http://www.se2009.eu/polopoly_fs/1.25171!menu/standard/file/111471.pdf 
Az Európai Bizottság hivatalos klaszter honlapja: Knowledge System for Lifelong Learning. http://www.kslll.net/Default.cfm. és http://ec.europa.eu/education/school-education/doc 2254_en.htm

Kulcsadatok az oktatásról 2009. Education, Audiovisual and Culture Executive Agency P9 Eurydice, Brüsszel, Eurydce.

Löfström, E., Eisenschmidt, E. (2009): Novice teachers' perspectives on mentoring: The case of Estonian induction year. Teaching and Teacher Education, 5. sz. 681-689.

Policies on the induction of new teachers. Peer Learning of cluster teachers and trainers. http://www.kslll.net/PeerLearningActivities/PlaDetails.cfm?id=80

Poom-Valickis, K. (2008): Supporting Novice Teachers' Professional Development. http://www.tlu.ee/?LangID=1\&CatID=3496\&ArtID=2735\&action=article

European Commission Staff Working Dokument (2010): Developing Coherent and Systemwide Induction Programmes for Beginning Teachers. A handbook for policymakers. http://ec.europa.eu/education/school-education/doc2254_en.htm

Penny, E. (2008): Teacher Induction in Scotland http://www.tlu.ee/?LangID=1\&CatID=3496\&ArtID=2735\&action=article

General Teaching Council of Scotland (Skócia Általános Tanári Tanácsa) hivatalos honlapja: http://www.gtcs.org.uk/Research_/publishedresearch_/TeacherInductionSchemeResea rch/research_teacher_induction_scheme.aspx

Eisenschmidt, E. (2008): Induction and Teacher's Professional Development: the Estonian. Project http://www.tlu.ee/?LangID=1\&CatID=3496\&ArtID=2735\&action=article 